\title{
Developing Critical-Thinking Skills through the Collaboration of Jigsaw Model with Problem-Based Learning Model
}

\author{
Maskhur Dwi Saputra \\ Faculty of Teacher Training and Education, Sebelas Maret University, Indonesia, \\ maskhurds.pascauns.fkip@gmail.com
}

Soetarno Joyoatmojo

Prof., Faculty of Teacher Training and Education, Sebelas Maret University, Indonesia

Dewi Kusuma Wardani

Dr., Faculty of Teacher Training and Education, Sebelas Maret University, Indonesia

\section{Khresna Bayu Sangka}

P.hD., Faculty of Teacher Training and Education, Sebelas Maret University, Indonesia

\begin{abstract}
This research aimed at examining the effectiveness of collaboration of Jigsaw and problem-based learning (PBL) model in developing students' critical thinking skills. This research exerted an experimental design using pre-experimental one group pretest-posttest. The implementation of such model collaboration was carried out in SMK Batik 1 Surakarta, Central Java, Indonesia by engaging 37 accounting students of class XI. Before and after the implementation of the twomodel collaboration, the students were given the tests of critical thinking skills which were set in the same composition. The research data were in the form of pretest and posttest scores which were analyzed by examining t-test and gain score whose calculation was assisted by SPSS 23 program. The result indicated that there was a difference between the pretest score and the posttest score with the significance level of $0,000<0,05$. The average of pretest and posttest scores respectively referred to 48,44 and 68,93 . Accordingly, the implementation of collaboration of Jigsaw and problem-based learning (PBL) model was effective in developing students' critical thinking skills. From this research finding, there was an impediment of time limitation in enacting the collaboration of the two models. This constraint happened while presenting the result of group discussion.
\end{abstract}

Keywords: critical-thinking skills, effectiveness, jigsaw, problem-based learning, teaching, learning

Citation: Saputra, M. D., Joyoatmojo, S., Wardani, D. K., \& Sangka, K. B. (2019). Developing Critical-Thinking Skills through the Collaboration of Jigsaw Model with Problem-Based Learning Model. International Journal of Instruction, 12(1), 1077-1094. https://doi.org/10.29333/iji.2019.12169a 


\section{INTRODUCTION}

Critical thinking is one of the skills that everyone in the $21^{\text {st }}$ century should master. The skills needed in the $21^{\text {st }}$ century are: (1) critical thinking $(78 \%)$; (2) information technology $(77 \%)$; (3) health and fitness $(76 \%)$; (4) collaboration $(74 \%) ;(5)$ innovation (74\%); (6) personal financial responsibility (72\%) (Kay, 2008). In addition, there are also some learning skills in the $21^{\text {st }}$ century such as critical thinking, problem solving, creative thinking, communication, and collaborative (Partnership for 21st Century Learning, 2015).

Critical thinking is included in expert judgement. The skill is needed in the world of work today that everyone should be able to master critical-thinking skills in order to compete in the world of work (Trilling \& Fadel, 2009). Critical thinking skills can be taught to everyone, one of which is through the world of education because education has an important role in shaping one's attitudes, knowledge, and skills.

Indonesia is one country that is very concerned about education for its people. The Law on National Education System (Sisdiknas) is the evidence that Indonesian government is very concerned about education (Undang-Undang Nomor 20, 2003). The purpose of education in Indonesia in article 3 is to develop the potentials of Indonesian people into human beings who have faith, morals, knowledge, and responsibility so that Indonesian society can compete with other countries in the mastery of science and technology (Undang-Undang Nomor 20, 2003).

Education in Indonesia can be done through a formal way that is by learning at schools. Vocational High School (VHS) is one of the formal education pathways in Indonesia that aims to prepare students to enter the world of work in accordance with their chosen fields of science. Vocational high school students should be able to master the skills required by the world of work (Velkovski \& Rizova, 2015), one of which is critical thinking. The basic framework and curriculum structure of VHS in Indonesia also mention that students of VHS should be taught about critical thinking skills (Peraturan Menteri Pendidikan dan Kebudayaan Republik Indonesia Nomor 70, 2013).

Critical thinking can be used in every area of life (Cottrell, 2015) that students can learn to think critically according to their chosen fields of interest. The field of knowledge in VHS is very diverse, one of which accounting. Students who choose the field of accounting can learn to think critically from the financial statement data. They can criticize the financial statement data, then justify the financial statements in case of errors according to the information they have learned previously. Accounting learning taught by critical thinking can be a provision for them when working in the business world (Reinstein \& Bayou, 1997).

The field of accounting has some special skills that must be mastered by students. These special skills include flexible thinking, analysis, critical thinking, and understanding of business (He, Craig, \& Wen, 2013). In addition, students who choose the field of accounting should be able to reason, process, and display information effectively, collaboratively, and using critical thinking (Direktorat Pembinaan Sekolah Menengah Kejuruan Nomor 330/D.D5/KEP/KR/2017). In addition, accounting needs to be taught 
in a critical way of thinking (Jones, 2010; Lehman, 2010). Based on the explanation above, it can be concluded that critical thinking is not only the demand of the $21^{\text {st }}$ century but also a special skill that must be mastered by students who choose the field of accounting.

Critical thinking skills are closely related to cognitive activity (Fisher, 2008). Such skills are part of the learning outcomes of the knowledge aspect of higher-order-thinking categories (FitzPatrick \& Schulz, 2015; Paul \& Elder, 2014). Critical thinking is an activity to give opinions, to assess, to observe, and to communicate (Fisher, 2008). In addition, critical thinking can be regarded as cognitive activity to perform analysis and evaluation (Cottrell, 2005). Assessing a reason correctly or identifying wrong opinions can be defined as critical thinking (Mason, 2008; Epstein, 2006).

Critical thinking can also be said to be an active learning process for agreeing or disagreeing with information, judging to determine the truth, and changing misinformation to create new ideas (Florea \& Hurjui, 2015). In addition, critical thinking can be defined as a meta-cognitive process consisting of several skills such as analysing, synthesizing, evaluating, and summarizing opinions or solutions appropriately to solve a problem (Dwyer et al., 2014). Based on some opinions above, it can be concluded that critical thinking is a skill to analyse, evaluate or assess, and provide justification for a wrong information.

Critical thinking includes the components of learning outcomes of the cognitive aspects of high-order-thinking categories, so critical thinking can be measured using test questions (Kartimi \& Liliasari, 2012; Syutharidho \& Rakhmawati, 2015; Pradana, Parno, \& Handayanto, 2017). The critical-thinking questions can be measured using the indicators of Bloom's Taxonomy (Pappas, Pierrakos, \& Nagel, 2013). The thinking levels of Bloom's Taxonomy consist of remembering, understanding, applying, analysing, synthesizing, and evaluating (Bloom, Engelhart, Furst, Hill, and Krathwohl; 1956). Then the thinking levels of Bloom's Taxonomy were revised to be remembering, understanding, applying, analysing, evaluating, and creating (Anderson and Krathwohl; 2010).

This research used the revised version of Bloom's Taxonomy thinking levels. Furthermore, the levels of thinking Bloom's Taxonomy are categorized into two namely low-level thinking (remembering, understanding, and applying) and high-level thinking (analysing, evaluating, and creating) (Magas et al., 2017). Furthermore, critical thinking is included in the higher-order-thinking categories (Dwyer et al., 2014; Puteh \& Hamid, 2014). So, critical thinking can be measured by analysing, evaluating, and creating (Dwyer et al., 2014).

The information in the field showed that the students who chose accounting in the VHS were not directed to develop their critical-thinking skills, because the learning process was still teacher-centred. The learning applied was in the form of lectures, so that the students were not given the opportunity yet to develop their critical thinking skills. In addition, test questions made by the teachers were still at the level of remembering $(\mathrm{C} 1)$, understanding $(\mathrm{C} 2)$, and applying (C3). The followings are the percentages of test- 
question levels made by the teachers: remembering $(\mathrm{C} 1)$ by $28.00 \%$; understanding $(\mathrm{C} 2)$ by $48.67 \%$; applying (C3) by $19.33 \%$; analysing (C4) by $4.00 \%$; evaluating (C5) by $0.00 \%$; and creating (C6) by $0.00 \%$.

Based on the conditions in the field, the students have not been directed to develop critical thinking skills. In addition, the test-questions made by the teachers also have not led to the mastery of critical thinking skills. Therefore, innovations are needed to overcome these problems. Critical thinking skills can be developed through discussions when the learning process is in progress (Schoenberger-Orgad \& Spiller, 2014). Discussions in learning can be undertaken by applying cooperative learning model because this model invites students to discuss with each other, work hand-in-hand, help each other, and invite each other to discuss a subject matter (Isjoni, 2009).

Cooperative learning model has several types. One type in the most common cooperative model is jigsaw. This type has special characteristics in terms of group formation. Jigsaw has more complex group structures; they are home group and expert group (Pozzi, 2010). The original groups are formed with the aim of assigning responsibilities to each group member and discussing the materials in general while the expert group is formed with the aim of studying more specific materials (Doymus, 2008).

The jigsaw cooperative model has the following procedures (1) Students form a home group consisting of 4-6 people; (2) The teacher explains the outline of the materials to be discussed; (3) Each member in the home group has responsibility for studying more specific materials; (4) Members who acquire the same materials come together with expert groups to discuss specific materials; (5) After completing the discussion, the group members in the expert group return to the home group to explain the materials they have obtained to the expert group; (6) At the end of the learning, test questions that must be done individually are given (Slavin, 1995; Artut \& Tarim, 2007; Gambari, Yusuf, \& Thomas, 2015).

The Jigsaw type of cooperative learning model encourages students to remember and understand the subject matter. The domains of remembering and understanding are shown by the activities of group members who explain each other the contents of the materials to the group so that the students have not developed critical-thinking skills maximally. Therefore, it is necessary to present a problem in the Jigsaw learning model that learners can develop their critical-thinking skills.

Learning process by presenting problems can encourage students to develop their critical-thinking skills because they are required to solve the problem. The process of problem-solving requires the thinking activities of analysing, evaluating, and creating an idea (Asyari, Al Muhdhar, Susilo, \& Ibrohim, 2016). The learning process by presenting the problem can be applied using Problem-Based Learning (PBL) model (Schechter, 2011; Eggen \& Kauchak, 2012).

Problem-Based Learning (PBL) model has a procedure that consists of (1) The teacher presents the problem to the students; (2) The students identify the given problem; (3) They seek informations from various sources to solve the problem; (4) They choose the 
most appropriate solution to solve the problem; (5) The teacher evaluates the students' works (Macklin, 2001; Eggen \& Kauchak; 2012; Gorghiu et al., 2015; Alrahlah, 2016).

Based on the explanation of the learning model above, teachers can make learning innovations so that the quality of education in schools can increase (Cvetkovic \& Stanojević, 2017) and they can improve the critical-thinking quality of students. Learning innovations to improve critical thinking can be done through the collaboration of Jigsaw learning model with problem-based learning model. The model collaboration can create a meaningful learning process because the materials they students have learned are directly applied to solve problems (Dahar, 2006). In addition, the role of teachers will change to be more interactive (Xhemajli, Cyril, \& Methodius, 2016).

Several studies using Jigsaw learning model and problem-based learning model have been conducted by previous researchers. The research on Jigsaw type of cooperative learning model has been proven to be effective in improving learning achievement and students' understanding (Doymus, 2008; Tran \& Lewis, 2012). The previous research applied Jigsaw learning model to find out the learning achievement and levels of students' understanding of a material. Meanwhile in this study, the collaboration of Jigsaw learning model with problem-based learning model was to develop students' critical-thinking skills.

A research on the integration of problem-based learning model with group-investigation model could improve critical-thinking skills (Asyari et al., 2016). The research integrated problem-based learning model with group-investigation model to improve critical-thinking skills while this study integrates a Jigsaw learning model with a problem-based learning model.

\section{Aim of the Research}

Based on the introduction described above, this research has the purpose of developing students' critical-thinking skills through the collaboration of Jigsaw cooperative learning model with problem-based learning model. Therefore, students can compete in the $21^{\text {st }}$ century today by using their critical-thinking skills.

\section{METHOD}

\section{Research Design}

This research was an experimental research with pre-experiment design of one group pretest-posttest. Pre-experimental research design is not yet a real experiment because there are still external variables that affect the dependent variable. The researcher used one group pretest-posttest design because there is a group that is given treatment and then the results are analysed by comparing the results of pretest (before treatment) and posttest (after treatment) (Creswell, 2008).

The treatment in this research was the treatment given to the students in the learning process. The treatment applied in the learning process used the collaboration between Jigsaw cooperative learning model and PBL model. The collaboration between the 
models was applied three times to discuss accounting materials. The procedures of the collaboration between the two models can be seen in Table 1 below:

Table 1

The Collaborative Procedures of Jigsaw Cooperative Learning Model with ProblemBased Learning Model.

\begin{tabular}{|c|c|c|}
\hline Jigsaw & PBL & Collaboration of Jigsaw and PBL \\
\hline $\begin{array}{l}\text { 1. Home-group formation. } \\
\text { 2. Group members read all the } \\
\text { materials to be discussed. } \\
\text { 3. Each member of the group } \\
\text { was assigned to learn more } \\
\text { specific sub-materials. } \\
\text { 4. Getting together with other } \\
\text { group members to discuss } \\
\text { the same sub-materials } \\
\text { (expert group). } \\
\text { 5. Members returned to the } \\
\text { home group to explain the } \\
\text { informations obtained from } \\
\text { the expert group. } \\
\text { Discussing the group work } \\
\text { with other group members. } \\
\text { Quiz. } \\
\text { (Slavin, 1995; Artut \& Tarim, } \\
\text { 2007; Gambari, Yusuf, \& } \\
\text { Thomas, 2015) }\end{array}$ & $\begin{array}{l}\text { 1. Providing problems } \\
\text { to the students. } \\
\text { 2. Students identified } \\
\text { the problem. } \\
\text { 3. Students sought } \\
\text { informations from } \\
\text { various sources. } \\
\text { 4. Students chose the } \\
\text { right solution to } \\
\text { solve the problem. } \\
\text { Teachers evaluated } \\
\text { the students' works } \\
\text { (Macklin, 2001; } \\
\text { Eggen \& Kauchak; } \\
\text { 2012; Gorghiu, } \\
\text { Drăghicescu, Cristea, } \\
\text { Petrescu, \& Gorghiu, } \\
\text { 2015; Alrahlah, 2016) }\end{array}$ & $\begin{array}{l}\text { 1. Forming home-group. } \\
\text { 2. Explaining the learning objectives that the } \\
\text { students must achieve. } \\
\text { 3. Giving a problem to each member of the } \\
\text { group. } \\
\text { 4. Asking group members to read the } \\
\text { materials to be discussed. } \\
\text { 5. Asking group members to identify the } \\
\text { problem. } \\
\text { 6roup members sought informations to } \\
\text { resolve the problem by assigning } \\
\text { responsibilities to each group member to } \\
\text { learn more specific sub-materials. } \\
\text { 7. Group members gathered with other } \\
\text { group members who got the same sub- } \\
\text { materials (expert group). } \\
\text { 8. Group members went back to the home } \\
\text { group to find the right solution to the } \\
\text { problem. } \\
\text { 9. Students described the group-works in } \\
\text { front of the class. } \\
\text { 10. The teacher assigned quiz or evaluation to } \\
\text { each student. }\end{array}$ \\
\hline
\end{tabular}

\section{Participants, Sampling, and Data Analysis}

This research was conducted in Surakarta City, Central Java Province, Indonesia. The sample in this research were SMK Batik 2 Surakarta. The try-out of the test instrument about critical-thinking skills was conducted in SMKN 1 Surakarta Central Java, Indonesia by engaging 37 accounting students of class XI. The sampling technique was cluster random sampling while the data analysis technique was using t-test and gain score.

\section{Research Instruments}

This research used the instrument in the form of test questions. The instrument was made according to the critical-thinking indicators which consist of analysing, evaluating, and creating. Below is the structure of test questions that have been validated: 
Table 2

The Structure of Critical-Thinking Skill Test Questions

\begin{tabular}{|c|c|c|}
\hline Critical-thinking indicators & Indicators of Competence Achievement & Number of Items \\
\hline \multirow{2}{*}{$\begin{array}{l}\text { Analysing } \\
\text { (differentiating, organizing, } \\
\text { attributing) }\end{array}$} & $\begin{array}{l}\text { Distinguishing the classification and its } \\
\text { recording system merchandise inventory. }\end{array}$ & 2,3 \\
\hline & $\begin{array}{l}\text { Distinguishing the methods used to } \\
\text { determine merchandise values. }\end{array}$ & 4 \\
\hline \multirow{2}{*}{$\begin{array}{l}\text { Evaluating } \\
\text { (checking, criticizing, judging) }\end{array}$} & Evaluating the merchandise inventory. & 1 \\
\hline & $\begin{array}{l}\text { Evaluating the use of methods in } \\
\text { determining merchandise value. }\end{array}$ & 5 \\
\hline $\begin{array}{l}\text { Creating } \\
\text { (formulating, planning, producing) }\end{array}$ & $\begin{array}{l}\text { Designing a merchandise card to calculate } \\
\text { merchandise values }\end{array}$ & 6 \\
\hline
\end{tabular}

The structure of test questions in Table 2 above has passed the feasibility test consists of 4 criteria; they are validity, reliability, discrimination power, and levels of difficulty (Budiyono, 2015). The implementation of such collaboration was carried out in three meetings. The details of the implementation are presented as follows:

Table 3

Students' activities during the implementation of collaboration of Jigsaw and problembased learning model

\begin{tabular}{|c|c|c|}
\hline Meeting & Learning Topics & Students' Achievements \\
\hline \multirow{2}{*}{$1^{\text {st }}$ Meeting } & $\begin{array}{l}\text { The definition of } \\
\text { merchandise inventory }\end{array}$ & $\begin{array}{l}\text { Students are able to evaluate the definition of } \\
\text { merchandise inventory }\end{array}$ \\
\hline & $\begin{array}{l}\text { The classification and } \\
\text { systems of inventory records }\end{array}$ & $\begin{array}{l}\text { Students are able to differentiate the classification } \\
\text { and systems of inventory records }\end{array}$ \\
\hline Meeting & Learning Topics & Students' Achevement \\
\hline \multirow{2}{*}{$2^{\text {nd }}$ Meeting } & \multirow{2}{*}{$\begin{array}{l}\text { The methods of merchandise } \\
\text { inventory }\end{array}$} & $\begin{array}{l}\text { Students are able to differentiate the methods used to } \\
\text { determine the value of inventory }\end{array}$ \\
\hline & & $\begin{array}{l}\text { Students are able to evaluate the application of } \\
\text { methods used to determine the value of inventory }\end{array}$ \\
\hline $3^{\text {rd }}$ Meeting & Designing inventory cards & $\begin{array}{l}\text { Students are able to design the inventory cards to } \\
\text { account the value of inventory }\end{array}$ \\
\hline
\end{tabular}

Direktorat Pembinaan Sekolah Menengah Kejuruan Nomor 330/D.D5/KEP/KR/2017

\section{FINDINGS}

This research applied the collaboration between Jigsaw cooperative learning model and PBL model. The research data were in the form of pretest and posttest scores which were analyzed by examining t-test and gain score. The t-test results using paired t-test consist of 3 outputs; they are paired samples statistics (gain score), paired samples correlations, and paired samples test.

The following is the explanation of the results of the three outputs: 
Table 4

The Results of Paired-Samples-Statistics Test

\begin{tabular}{lll}
\hline & Mean & N \\
\hline Pretest & 48,44 & 39 \\
\hline Posttest & 69,23 & 39 \\
\hline
\end{tabular}

Table 4 above showed that pretest-and-posttest data are respectively as many as 39 respondents. Furthermore, from 39 respondents, the average pretest score is 48,44 while the average posttest score is 69,23 .

Table 5

The Results of Paired-Samples-Statistics Test

\begin{tabular}{cccc}
\hline & df & Mean & Sig. \\
\hline Pretest-Posttest & 38 & 20,795 & 0,000 \\
\hline
\end{tabular}

Table 5 above is the final result to see if there is a difference between the pretest and posttest scores. The difference between the pretest score and posttest score is called the gain score. Based on the results from table 5 above, it can be seen that the significance shows a score of 0,000 and the score is less than the significance level of $0.05(0.000<$ $0,05)$, so it can be concluded that the pretest and posttest scores are not the same or different. The difference between the pretest and posttest scores is shown by an average difference of 20,795 .

The following is the average pretest and posttest results of students' critical-thinking skills:

Table 6

The Average Scores of Pretest and Posttest of Critical Thinking Skills

\begin{tabular}{lcccc}
\hline & N & Min & Max & Mean \\
\hline Pretest & 39 & 20 & 71 & 48,44 \\
Posttest & 39 & 62 & 87 & 69,23 \\
\hline
\end{tabular}

Table 6 above shows the average of pretest and posttest scores. The results of the calculations show that the average pretest score is 48,44 while the average posttest score is 69,23 . Therefore, it can be concluded that the average posttest score is greater than the average pretest score. The gain score of both pretest and posttest is 20,795 .

\section{DISCUSSION}

Based on the results of the research that has been done, there was a significant difference between the scores of pretest and posttest with a significance score of 0,000 . The average pretest score is 48,44 and the average posttest score is 69,23 , In addition, the gain score obtained from the average score of pretest and posttest is 20.795. Thus, the application of the collaboration between Jigsaw cooperative learning model and problem-based learning model is effective to improve students' critical-thinking skills. The result of this research aligns with the prior study which reveals that the collaboration of learning models can encourage students to enhance their critical thinking skills (Palennari, 2011; Asyari et al., 2016). 
This research collaborated Jigsaw learning model with problem-based learning model. In the Jigsaw learning model, students are responsible for the subject matter, helping each other with difficulties understanding the subject matter, making effective interactions with their friends, and being actively involved in the learning process (Şahin, 2010; Maden, 2011; Esnawy, 2016). The activities that students do on the Jigsaw learning model help them to understand the subject matter.

The learning process applied with the Jigsaw model is then collaborated with the problem-based learning model so that the learning process was more effective to train the critical-thinking skills of students. Critical thinking includes high-order thinking skills (Trilling \& Fadel, 2009; FitzPatrick \& Schulz, 2015). In addition, high-order thinking skill requires thinking activities of analysing, evaluating, and making conclusions (Paul \& Elder, 2014; Widiawati, Joyoatmojo, \& Sudiyanto, 2018). Therefore, problem-based learning model is appropriate to encourage students to improve their critical-thinking skills (Şendağ \& Ferhan Odabaşi, 2009; Alrahlah, 2016; Gholami et al., 2016).

The implementation of problem-based learning model is done by bringing the problem when the learning process takes place (Chen \& Chang, 2014; Alrahlah, 2016). The problem used can encourage students to think critically (analysing, evaluating, and creating or making conclusions) (Gholami et al., 2016; Şendağ \& Ferhan Odabaşi, 2009). Students in solving problems not only need to understand the materials but also need to analyse, evaluate, and make conclusions on the subject matter to find solutions to the problem.

The collaborative procedure of Jigsaw and problem-based learning model gives an opportunity for students to develop their critical thinking skills. In this research, to implement the procedure, the first step was to make a home group whose members were heterogeneously spread and coordinated by the teacher. Anchored in the previous meeting, the teacher had already split the students into 6 groups containing 6 to 7 persons each. This research utilized the groups already set by the teacher.

The second step was oriented to the activity whereby the teacher explained the learning objectives which should be achieved by the students. Those objectives conformed to the learning material that became the topic for the meeting. This research used financial accounting as the learning material with the topic addressing the issue of merchandise inventory whose learning processes were classified into three meetings. Pertinent to the learning objectives, at the first meeting, the students were able to evaluate the definition of merchandise inventory, differentiate the classification of inventory, and differentiate the systems of inventory records. At the second meeting, the students were able to differentiate and evaluate the methods of merchandise inventory. At the third meeting, the students were able to design the inventory cards used to account the value of inventory.

The third step went to the activity whereby the teacher gave a case study to students in each group. The given case study was associated with the material topic of each meeting. For instance, a case study at the first meeting extended to the activity of 
analyzing the story matters about the process of making tofu. In turn, the students were asked to mention the kind of company producing the tofu as well as to classify the types of inventory had by that company. The case study given at the second meeting was about an evaluation activity. Here, the students were given some data with respect to the purchase and sale of merchandise. Anchored in those data, there was further provided a table of the inventory value accounting which was intentionally made and displayed incorrectly by using the method of FIFO (First In First Out). In this condition, the students had to be able to evaluate whether the method employing FIFO used to account the value of inventory was correct or not. Furthermore, the students had to come up with their opinions vis-a-vis their chosen answer of evaluation. The given case study at the third meeting was about creating. In this condition, some data as regards the purchase and sale of inventory were given to the students, and then the students were instructed to insert those data into the inventory cards. Thus, to do this, they had to design and make the inventory cards in prior.

Appertaining to the fourth step, the students were guided to read all of the topics specifically given in each meeting. For instance, at the first meeting, they read the topics corresponding to the definition of inventory, the classification of inventory, and the system of inventory records. At the second meeting, they read the entire topics with regard to the methods of accounting the value of inventory. In addition, at the third meeting, they read the topics in association with the means of designing inventory cards. Reading all related topics as such is functional to give the students a sort of initial comprehension related to some information which they subsequently had to seek to deal with the given case study.

Concerning with the fifth step, the students' activity was to identify the learning problems as guided by the teacher. At the first meeting, they mostly still found it difficult to identify the given problems, so when the learning process was going on, they were very enthusiastic about posing a number of questions to the teacher. In turn, along with the proper instruction given by the teacher, they were starting to understand of identifying the problems emerged in the given case study. At the second and third meeting, they continuously understood more the means of identifying the case study problems so that in those meetings they did not ask too many questions as they did at first.

At the sixth step, each group left each member in charge of learning the topics more specifically. For instance, at the first meeting whose learning topics extended to four sub-topics such as the definition of inventory, the classification of inventory, and the system of inventory records comprised of periodic and perpetual system, let us say such as the first group (harta) containing 7 persons, this group left each member in charge whereby 1 person was assigned to learn the definition of inventory, 2 persons were demanded to learn about the classification of inventory, 2 persons were assigned to learn about the inventory record of periodical system, and the rest 2 persons were demanded to learn about the perpetual system.

The seventh step went to the activity whereby each member of each group who had previously been in charged with a task would gather with other group members who had 
the same focused topics. At this step, the students made an expert group to seek a great amount of specific information in order to solve the problem of the given case study as previously assigned in the home group. The teacher guided students to search for some information from a variety of sources, so that the students' knowledge of the related topics could vastly increase. At the eighth step, each student came back to the home group respectively in order to hold a discussion under the purpose of solving the assigned case study problems by using the information gained from the expert group. In this activity, the students shared each other their perspectives while dealing with the problem solving activity.

At the ninth step, the learning activity went to presenting the result of group discussion. At this step, the teacher only gave an opportunity to two groups to present the result of their discussion in front of the class. A fundamental reason of why the teacher did not give the chance to all groups was because of the insufficient allocation of time. In this activity, lots of students enthusiastically shared their criticisms and suggestions for the groups that presented their discussion result. At the tenth step, the teacher gave quizzes to students in order to be individually coped with. The students were not allowed to ask others or make an effort to find out the answers from some sources. The quizzes were functionally given to know the students' critical thinking skills.

The implementation of collaborative Jigsaw learning model with problem-based learning model begins with the problem given by the teacher. Providing such issues is the characteristic of problem-based learning model (Schechter, 2011; Eggen dan Kauchak, 2012). The provision of such problems is done with the aim to stimulate students to solve problems by analysing, evaluating, and inferring from the information they have obtained (Dwyer et al., 2014; Fajrianthi, Hendriani, \& Septarini, 2016). The activities of analysing, evaluating and summarizing are the indicators of critical thinking (Vong \& Kaewurai, 2017).

The development of critical thinking skills is also seen when the students have a group discussion. That the students hold a discussion in the home group and expert group draws on a typical characteristic of Jigsaw learning model (Evcim \& İpek, 2013; Şengül \& Katranci, 2014; Leyva-Moral \& Riu Camps, 2016). In home group, the students are engaged in two activities namely identifying problems and having a discussion to solve the problems emerged in the given case study. In turn, in the expert group, the students deal with the activity to search for more specific information (Slavin, 1995; Artut \& Tarim, 2007; Gambari et al., 2015).

An activity such as identifying problems in the home group is a type of problem-based learning model (Arends, 2001). This activity triggers students to understand the given case study in prior before searching for more information. The process of understanding the case study as such refers to the second level of thinking indicator as indicated in Bloom Taxonomy (Anderson and Krathwohl, 2010). The students have to firstly do the activities representing a lower level of thinking before they deal with the activities typifying a high level of thinking. This way aims at facilitating the students to capably solve the learning problems properly. 
The activity of searching for information in the expert group is undertaken by holding a discussion with other group members who have been in charged with the same topic. Such activity is categorized as the implementation of problem-based learning model (Macklin, 2001; Eggen \& Kauchak; 2012; Gorghiu, Drăghicescu, Cristea, Petrescu, \& Gorghiu, 2015; Alrahlah, 2016). The students can seek some information from a variety of learning sources in order to enhance their knowledge while solving the problems sensitized in the given case study.

Discussion activity in the home group is carried out after the students have done the activity of seeking specific information in the expert group. In such discussion, the students deal with problem solving activity for the case study given by the teacher. The problem solving process requires some activities such as analyzing, evaluating, as well as creating, and then those activities are integrated in each meeting of the learning process as depicted in table 3 (Dwyer et al., 2014; Schoenberger-Orgad \& Spiller, 2014; Samejima, Hisakane, \& Komoda, 2015; Fajrianthi, Hendriani, \& Septarini, 2016). In addition, the processes of analyzing, evaluating, and creating carried out in every meeting are called critical thinking activities (Vong \& Kaewurai, 2017).

At the end of the learning process, the teacher instructs students to present the result of their group discussion in front of the class. At this stage, the teacher only gives an opportunity to two groups in order to present their discussion result. This stage basically does not align with the theory of Jigsaw and problem-based learning model which states that all groups should ideally present the result of their work in order to get feedback (Slavin, 1995; Macklin, 2001; Artut \& Tarim, 2007; Eggen \& Kauchak; 2012; Gambari, Yusuf, \& Thomas, 2015; Gorghiu, Drăghicescu, Cristea, Petrescu, \& Gorghiu, 2015; Alrahlah, 2016). Anchored in this research result, even though not all groups have a chance to present their work result, the students from other groups in fact keep being actively engaged in the whole class discussion by giving their criticisms and suggestions. While providing their comments and suggestions, the students are actually trained to evaluate the work of other groups. This way encourages them to do the activity of evaluation as portrayed in Bloom Taxonomy (Anderson and Krathwohl, 2010; Hosnan, 2014).

At the end of the lesson, they will do the test individually. The test-questions are made according to the indicators of critical thinking. The test blueprint used to measure students' critical-thinking skills is shown in Table 2 above. Answering the test questions also requires the activities of analysing, evaluating, and making conclusions or creating. Students have been practising analysing, evaluating, and making conclusions or creating that it is easier for them to answer the test questions. After they take the test, the teacher will reward those who get the highest score (Slavin, 1995; Artut \& Tarim, 2007; Gambari et al., 2015). 


\section{CONCLUSION}

Based on the results of the research, the conclusion of this research is that the application of collaboration between Jigsaw cooperative learning model and problembased learning model effectively developing the critical-thinking skills of VHS students of accounting department. The effectiveness is indicated by the difference in the average pretest and posttest scores. The average pretest score of 48.44 is smaller than the average posttest score of 69.23 . The average difference between the pretest and posttest scores is 29.795 .

This research finding indicates that the implementation of collaboration of Jigsaw and problem-based learning model is effective in developing the accounting students' critical thinking skills. The students are able to develop their critical thinking skills inasmuch as they are actively engaged in group discussion activity while solving the problems sensitized in the case study given by the teacher at the beginning of learning process. Solving such case study requires a couple of activities such as analyzing, evaluating, and creating as those activities conform to the indicators of critical thinking. The implementation of collaboration of Jigsaw and problem-based learning model takes a quite long time. It can be seen from the condition whereby the teacher can only give a chance to merely two groups in order to present their work result by virtue of the time issue.

\section{RECOMMENDATIONS}

For all parties that are going to implement the collaboration of Jigsaw and problembased learning model, it is recommended that they pay extra attention to consider the time needed in enacting the learning procedures. Being cautious about time is of importance in this case in order to manage to successfully and appropriately implement the collaboration of the Jigsaw and problem-based learning model. From this point, consider to the time consuming of jigsaw's implementation, it is very important to create an effective and solid preparation for this method. Furthermore, teachers preparedness to apply jigsaw model depends on theirs critical thinking on specific theme observing and setting. Critical thinking itself could only achieved if the teachers have ability to see a problematic phenomenon from different point of views. This would become the future directions for further research.

\section{ACKKNOWLEDGEMENTS}

The researcher would like to thank the teachers of accounting study program at SMKN 1 and SMK Batik 2 Surakarta, Central Java Province, Indonesia who have assisted in this research process. In addition, the researcher also expresses his gratitude to the lecturers of the Master of Economics Education, Sebelas Maret University, Indonesia who have given their constructive comments and suggestions for the better composition of this article. 


\section{REFERENCES}

Anderson, L. W., dan Krathwohl, D. R. (2001). A Taxonomy for Learning, Teaching, and Assessing: A Revision of Bloom's Taxonomy of Educational Objectives. New York, NY: Longman.

Alrahlah, A. (2016). How Effective the Problem-Based Learning (PBL) in Dental Education. A Critical Review. The Saudi Dental Journal, 28, 155-161. https://doi.org/10.1016/j.sdentj.2016.08.003.

Arends, R. I. (2001). Learning to Teach Fifth Edition. New York, NY: McGraw-Hill International Edition.

Artut, P. D., \& Tarim, K. (2007). The effectiveness of jigsaw ii on prospective elementary school teachers. Asia-Pacific Journal of Teacher Education, 35(2), 129 141. https://doi.org/10.1080/13598660701268551.

Asyari, M., Al Muhdhar, M. H. I., Susilo, H., \& Ibrohim. (2016). Improving critical thinking skills through the integration of problem based learning and group investigation. International Journal for Lesson and Learning Studies, 5(1), 36-44. https://doi.org/10.1108/IJLLS-10-2014-0042.

Chen, C., \& Chang, C. (2014). Mining learning social networks for cooperative learning with appropriate learning partners in a problem-based learning environment. Interactive $\begin{array}{lll}\text { Learning Environments, 22(1), 97-124. } & \end{array}$ https://doi.org/10.1080/10494820.2011.641677.

Cvetković, B. N., \& Stanojević, D. (2017). Educational needs of teacher for introduction and application of innovative models in educational work to improve teaching. International Journal of Cognitive Research in Science, Engineering and Education (IJCRSEE), 5(1), 49-56. https://doi.org/10.5937/IJCRSEE1701049N.

Direktorat Pembinaan Sekolah Menengah Kejuruan Nomor 330/D.D5/KEP/KR/2017 Kompetensi Inti dan Kompetensi Dasar SMK/MAK: Kompetensi Keahlian Akuntansi dan Keuangan Lembaga.

Doymus, K. (2008). Teaching chemical equilibrium with the jigsaw technique. Research in Science Education, 38(2), 249-260. https://doi.org/10.1007/s11165-007-9047-8.

Dwyer, C. P., Hogan, M. J., \& Stewart, I. (2014). An integrated critical thinking framework for the 21st century. Thinking Skills and Creativity, 12, 43-52. https://doi.org/10.1016/j.tsc.2013.12.004.

Evcim, H., \& İpek, Ö. F. (2013). Effects of jigsaw ii on academic achievement in english prep classes. Procedia - Social and Behavioral Sciences, 70, 1651-1659. https://doi.org/10.1016/j.sbspro.2013.01.236.

Fajrianthi., Hendriani, W., \& Septarini, B. G. (2016). Pengembangan Tes Berpikri 
Kritis dengan Pendekatan Item Response Theory. Jurnal Penelitian Dan Evaluasi Pendidikan, 20(1), 45-55. https://doi.org/http://dx.doi.org/10.21831/pep.v20i1.6304.

FitzPatrick, B., \& Schulz, H. (2015). Do curriculum outcomes and assessment activities in science encourage higher order thinking? Canadian Journal of Science, Mathematics and Technology Education, 15(2), 136-154. https://doi.org/10.1080/14926156.2015.1014074.

Florea, N. M., \& Hurjui, E. (2015). Critical thinking in elementary school children. Procedia - Social and Behavioral Sciences, 180, 565-572. https://doi.org/10.1016/j.sbspro.2015.02.161.

Gambari, A. I., Yusuf, M. O., \& Thomas, D. A. (2015). Effects of computer-assisted stad, Itm and ici cooperative learning strategies on nigerian secondary school students' achievement, gender and motivation in physics. The Malaysian Online Journal of Educational Science, 3(4), 11-26. Retrieved from https://eric.ed.gov/?id=EJ1085925.

Gholami, M., Moghadam, P. K., Mohammadipoor, F., Tarahi, M. J., Sak, M., Toulabi, T., \& Pour, A. H. H. (2016). Comparing the effects of problem-based learning and the traditional lecture method on critical thinking skills and metacognitive awareness in nursing students in a critical care nursing course. Nurse Education Today, 45, 16-21. https://doi.org/10.1016/j.nedt.2016.06.007.

Gorghiu, G., Drăghicescu, L. M., Cristea, S., Petrescu, A.-M., \& Gorghiu, L. M. (2015). Problem-based learning - an efficient learning strategy in the science lessons context. Procedia - Social and Behavioral Sciences, 191, 1865-1870. https://doi.org/10.1016/j.sbspro.2015.04.570.

He, H., Craig, R., \& Wen, J. (2013). Developing critical thinking skills and effective cooperative international accounting degree programs in China. Asian Review of Accounting, 21(2), 144-159. https://doi.org/10.1108/ARA-02-2013-0012.

Hosnan, M. (2014). Pendekatan Saintifik dan Kontekstual dalam Pembelajaran Abad 21 Kunci Sukses Implementasi Kurikulum 2013. Bogor: Ghalia Indonesia.

Kartimi., \& Liliasari. (2012). Implementasi pengembangan alat ukur berpikir kritis pada konsep kesetimbangan kimia untuk Siswa SMA. Jurnal Scientiae Educatia, 1(2), 1-22. http://dx.doi.org/10.24235/sc.educatia.v1i2.505.

Kay, K. 17 January, 2008. Preparing Every Child for the 21st Century. Paper Presented In APEC EdNet - Xi'an Symposium, China. Retrived from http://www.seiservices.com/APEC/ednetsymposium/downloads/Partnershipfor21Centur ySkills.pdf.

Leyva-Moral, J. M., \& Riu Camps, M. (2016). Teaching research methods in nursing using aronson's jigsaw technique. a cross-sectional survey of student satisfaction. Nurse Education Today, 40, 78-83. https://doi.org/10.1016/j.nedt.2016.02.017. 
Macklin, A. S. (2001). Integrating information literacy using problem based learning. Reference Services Review, 306-314. https://doi.org/10.1108/EUM0000000006493.

Magas, C. P., Gruppen, L. D., Barrett, M., Dedhia, P. H., \& Sandhu, G. (2017). Intraoperative questioning to advance higher-order thinking. American Journal of Surgery, 213(2), 222-226. https://doi.org/10.1016/j.amjsurg.2016.08.027.

Palennari, M. (2011). Potensi Strategi Integrasi PBL dengan Pembelajaran Kooperatif Jigsaw dalam Meningkatkan Pemahaman Konsep Mahasiswa. Jurnal Ilmiah Pendidikan Biologi, Biologi Edukasi, 3(2), 26-33. Retrieved from http://www.jurnal.unsyiah.ac.id/JBE/article/view/466.

Pappas, E., Pierrakos, O., \& Nagel, R. (2013). Using Bloom's taxonomy to teach sustainability in multiple contexts. Journal of Cleaner Production, 48, 54-64. https://doi.org/10.1016/j.jclepro.2012.09.039.

Partnership for 21st Century Learning. (2015). P21 Partnership for 21st Century Learning. Partnership for 21 st Century Learning. Washington DC: Author. Retrieved from http://www.p21.org/documents/P21_Framework_Definitions.pdf.

Paul, R., \& Elder, L. (2014). Critical Thinking: tools for taking charge of your professional and personal life. Retrieved from http://ptgmedia.pearsoncmg.com/images/9780133115284/samplepages/0133115283.pdf

Peraturan Menteri Pendidikan dan Kebudayaan Republik Indonesia 2013 Nomor 70 Kerangka Dasar dan Struktur Kurikulum Sekolah Menengah Kejuruan/Madrasah Aliyah Kejuruan.

Pozzi, F. (2010). Using jigsaw and case study for supporting online collaborative learning. Computers and Education, 55(1), 67-75. https://doi.org/10.1016/j.compedu.2009.12.003.

Pradana, S. D. S., Parno., \& Handayanto, S. K. (2017). Pengembangan Tes Kemampuan Berpikir Kritis Pada Materi Optik Geometri Untuk Mahasiswa Fisika. Jurnal Penelitian Dan Evaluasi Pendidikan, 21(1), 51-64. http://dx.doi.org/10.21831/pep.v21i1.13139.

Puteh, M. S., \& Hamid, F. A. (2014). A test on critical thinking level of graduating bachelor of accounting students: Malaysian Evidence. Procedia - Social and Behavioral Sciences, 116, 2794-2798. https://doi.org/10.1016/j.sbspro.2014.01.658.

Reinstein, A., \& Bayou, M. E. (1997). Critical thinking in accounting education: processes, skills and applications. Managerial Auditing Journal, 12(7), 336-342. https://doi.org/10.1108/02686909710180698.

Şahin, A. (2010). Effects of jigsaw II technique on academic achievement and attitudes to written expression course. Educational Research and Reviews, 5(12), 777-787. 
Retrieved from http://www.academicjournals.org/err/PDF/Pdf 2010/Dec/Sahin.pdf\%5Cnhttp://www.academicjournals.org/ERR/PDF/Pdf 2010/Dec/Sahin.pdf.

Samejima, M., Hisakane, D., \& Komoda, N. (2015). Automatic annotation method on learners' opinions in case method discussion. Interactive Technology and Smart Education, 12(2), 90-99. https://doi.org/10.1108/ITSE-04-2015-0003.

Schechter, C. (2011). Switching cognitive gears problem-based learning and successbased learning as instructional frameworks in leadership education. Journal of $\begin{array}{lll}\text { Educational Administration, } & \text { 49(2), } & \text { 143-165. }\end{array}$ https://doi.org/10.1108/09578231111116707.

Schoenberger-Orgad, M., \& Spiller, D. (2014). Critical thinkers and capable practitioners. Journal of Communication Management, 18(3), 210-221. https://doi.org/10.1108/JCOM-11-2012-0085.

Şenda, S., \& Ferhan Odabaşi, H. (2009). Effects of an online problem based learning course on content knowledge acquisition and critical thinking skills. Computers and Education, 53, 132-141. https://doi.org/10.1016/j.compedu.2009.01.008.

Şengül, S., \& Katranci, Y. (2014). Effects of jigsaw technique on mathematics selfefficacy perceptions of seventh grade primary school students. Procedia - Social and Behavioral Sciences, 116, 333-338. https://doi.org/10.1016/j.sbspro.2014.01.217.

Syutharidho., \& Rakhmawati, R. (2015). Pengembangan Soal Berpikir Kritis Untuk Siswa SMP Kelas VIII. Al-Jabar: Jurnal Pendidikan Matematika, 6(2), 219-227. Retrieved from http://ejournal.radenintan.ac.id/index.php/al-jabar/article/view/45.

Tran, V. D., \& Lewis, R. R. (2012). Effects of cooperative learning on students at an Giang University in Vietnam. International Education Studies, 5(1), 86-99. https://doi.org/10.5539/ies.v5n1p86

Trilling, B., \& Fadel, C. (2009). 21st Century Skills Learning for Life in Our Times. San Francisco: Jossey-Bass.

Undang-Undang Republik Indonesia Nomor 20 Tahun 2003 Sistem Pendidikan Nasional Indonesia.

Velkovski, Z., \& Rizova, E. (2015). Social dialogue and partnership in vocational education and training. International Journal of Cognitive Research in Science, Engineering and Education (IJCRSEE), 3(1), 81-88. Retrieved from http://www.ijcrsee.com/index.php/IJCRSEE/article/download/68/111?inline=1.

Vong, S. A., \& Kaewurai, W. (2017). Instructional model development to enhance critical thinking and critical thinking teaching ability of trainee students at regional teaching training center in Takeo Province, Cambodia. Kasetsart Journal of Social Sciences, 38, 88-95. https://doi.org/10.1016/j.kjss.2016.05.002. 
Widiawati, L., Joyoatmojo, S., \& Sudiyanto. (2018). Higher order thinking skills as effect of problem based learning in the 21st century learning. International Journal of Multicultural and Multireligious Understanding, 5(3), 96-105. Retrieved from https://ijmmu.com/index.php/ijmmu/article/view/223/139.

Xhemajli, A., Cyril, \& Methodius. (2016). The Role of the teacher in interactive teaching. International Journal of Cognitive Research in Science, Engineering and Education (IJCRSEE), 4(1), 31-38. https://doi.org/10.5937/IJCRSEE1601031X. 